\title{
Chlorophytum borivilianum (Safed Musli) root extract prevents impairment in characteristics and elevation of oxidative stress in sperm of streptozotocin-induced adult male diabetic Wistar rats
}

\author{
Nelli Giribabu', Kilari Eswar Kumar², Somesula Swapna Rekha ${ }^{3}$ Sekaran Muniandy ${ }^{4}$ and Naguib Salleh*
}

\begin{abstract}
Background: We hypothesized that C. borivilianum root, known to improve male reproductive performance, prevents impairment in characteristics, morphology and elevation of oxidative stress in sperm of diabetics. We therefore investigated the effect of aqueous root extract of $C$. borivilianum on these parameters in diabetic rat model.

Methods: C. borivilianum root aqueous extract ( 250 and $500 \mathrm{mg} / \mathrm{kg} /$ day) or glibenclamide $(600 \mathrm{\mu g} / \mathrm{kg} /$ day) were administered to streptozotocin (STZ)-induced diabetic male rats for 28 consecutive days. At the end of treatment, animals were sacrificed and sperm were collected. Sperm count and percentages of forward motility, viability, hypoosmotic swelling (HOS) tail-coiled and abnormal sperm were evaluated. Sperm lipid peroxidation product $(\mathrm{LPO})$, hydrogen peroxide $\left(\mathrm{H}_{2} \mathrm{O}_{2}\right)$ and nitric oxide $(\mathrm{NO})$ levels, total antioxidant capacity $(T A C)$, activity levels of endogenous antioxidant enzymes (superoxide dismutase-SOD, catalase-CAT and glutathione peroxidase-GPx), epididymal sperm density, serum fasting blood glucose (FBG) and $\mathrm{HbA} 1 \mathrm{c}$ levels were measured. The expression of sperm caspase-3 was assessed. Meanwhile, in-vitro free radical scavenging activity of $C$. borivilianum root extract was determined and the root extract was analyzed for the presence of bioactive compounds by FTIR spectroscopy.

Results: C. borivilianum root aqueous extract prevents the decrease in sperm count, percentages of forward motility, viability, HOS and the increase in abnormal sperm percentage and caspase-3 level in diabetic rats. Sperm $L P O, \mathrm{H}_{2} \mathrm{O}_{2}$ and NO levels, FBG and HbA1c were lower while TAC, SOD, CAT, GPX and epididymal sperm density were higher in diabetic rats receiving $C$. borivilianum root extract treatment. C. borivilianum root exhibited strong in-vitro free radical scavenging activity which may be due to the phenolic compound.

Conclusions: $C$. borivilianum root extract prevents impairment in sperm characteristics and morphology via preventing elevation of oxidative stress, apoptosis and free radicals levels of the sperm in diabetes. These effects may be achieved through maintaining sperm antioxidant level which could be related to free radical scavenging activity of the root extract by phenolic compounds. These effects could also be due to ability of the extract to maintain near normal serum FBG and HBA1c levels in diabetes.
\end{abstract}

Keywords: C. borivilianum, Diabetes mellitus, Sperm, Oxidative stress

\footnotetext{
*Correspondence: naguib.salleh@yahoo.com.my

'Department of Physiology, Faculty of Medicine, University of Malaya, 50603

Kuala Lumpur, Malaysia

Full list of author information is available at the end of the article
} 


\section{Background}

Diabetes mellitus (DM), characterized by chronic hyperglycemia resulting from deficiency of insulin secretion, resistance to insulin action or both, is associated with long-term damage, dysfunction and failure of various organs [1]. An alarming high rate of infertility has been reported in diabetic male [2]. Diabetes was found to adversely affect the sperm. Rama Raju et al., [3] reported that diabetic men have high percentage of sperm nuclear DNA fragmentation and apoptosis. Meanwhile, Thakur et al., [4] reported that hyperglycemia in rats diminished sperm count, seminal fluid fructose and antioxidant enzymes. A recent study by Battacharya et al., [5] reported that husbands of infertile couples with diabetes possess lower volume of ejaculates, sperm count and percentage of motile sperm as compared to healthy husbands of couples with proven fertility.

Safed Musli or Chlorophytum borivilianum (family: Lilliaceae) is a highly valued medicinal plant in India and is considered as "white gold" in Indian system of Ayurveda [6]. This plant has been reported to possess a number of biological activities including antimicrobial, anti-inflammatory, antipyretic, hepatoprotective, antioxidant, hypolipidemic and antidiabetic [7]. Traditionally, C. borivilianum root has been used to treat male impotence, oligozoospermia and erectile dysfunction [8]. Kenjale et al., [9] reported that oral administration of $250 \mathrm{mg} / \mathrm{kg} /$ day of C. borivilianum root aqueous extract to normal, healthy male rats preserved sperm count while Thakur et al., [10] reported that oral administration of $200 \mathrm{mg} / \mathrm{kg} /$ day of this plant extract to adult hyperglycemic male rats provides protection against sexual dysfunction as indicated by high frequency mounting, intromission and ejaculation.

Oxidative stress-induced sperm damage has been suggested as an important pathological mechanism underlying male infertility [11]. The sperm plasma membrane is susceptible to oxidation due to high content of polyunsaturated fatty acids (PUFA) [12]. Lipid peroxidation in sperm membrane can cause various impairments including decreased sperm motility [13]. The sperm could be protected from oxidative damage by endogenous antioxidant enzymes which are found both in sperm [14] and seminal fluid [15]. Meanwhile, the decrease in seminal fluid antioxidant level was reported to contribute to male infertility in humans [16].

We hypothesized that $C$. borivilianum root prevents impairment in sperm characteristics and morphology, oxidative stress and apoptosis in diabetic rats. This study therefore aimed to investigate $C$. borivilianum root extract effect on these sperm parameters in diabetes and to extent the previous observations in normal male rats whereby oral administration of this plant root extract improved male reproductive capability $[9,10]$.

\section{Methods}

\section{Drugs and chemicals}

Streptozotocin was purchased from Sigma Aldrich (St. Louis, MO, USA). All other chemicals used were of analytical grade.

\section{Plant collection and preparation of plant extract}

Dried roots of C. borivilianum were procured from Nandan Agro Farms Pvt. Ltd. (Hyderabad, Andhra Pradesh, India) and authenticated by senior botanist, Madhava Setty, Sri Venkateswara University, Tirupati, India. The plant was deposited at Herbarium with the number: KLU 96568. The dried roots were cut into small pieces and grounded into fine powder. The root powder (1000 g) was subjected to cold maceration in $2 \mathrm{~L}$ of sterile distilled water for 48 hours at room temperature, filtered into a clean round bottom flask using adsorbent cotton wool and a filter paper (Whatman No. A-1). The whole process was repeated seven times to ensure maximum yield of water soluble compounds from the root powder. The combined aqueous extract was concentrated at $37^{\circ} \mathrm{C}$ using a rotary evaporator (R-210, Buchi Labortechnik AG, Flawil, Switzerland) and lyophilized by using a cyodos freeze dryer (Telstar, Barcelona, Spain) to yield approximately $38 \mathrm{~g}$ of solid extract $(3.8 \% \mathrm{w} / \mathrm{w})$.

\section{Phytochemical screening}

A qualitative phytochemical evaluation was performed on the aqueous root extracts to determine the presence of carbohydrates (Barfoed's test), flavonoids (test of Shinoda), phytosterols (Libermann Buchard test), phenols (ferric chloride test), alkaloids (Dragendorff test), proteins (Biuret test) and saponins (Saponification test) following the methods as described by Harbourne [17].

\section{Fourier transform infrared (FTIR) spectroscopy}

FTIR spectroscopic analysis was performed using Perkin Elmer spectrophotometer system (PerkinElmer, Inc., Shelton, CT, USA) which detects the characteristic peaks and functional groups that are present in the root extract. The spectral range 4000 to $600 \mathrm{~cm}^{-1}$ with resolution of $2 \mathrm{~cm}^{-1}$ was used to record the infrared spectra with the potassium bromide $(\mathrm{KBr})$ pellet making technique.

\section{Experimental animals}

Adult male Wistar rats (170-200 g) were obtained from Animal House, Faculty of Medicine, University of Malaya (UM). The rats were kept under standard environmental conditions of room temperature $25 \pm 2^{\circ} \mathrm{C}$, relative humidity between $45-55 \%$ and $12 \mathrm{hrs}$ light/dark cycle. Animals were fed with standard feed pellets (Harlan diet, UK) and tap water ad libitum. Experimental procedures were in accordance with ARRIVE guidelines (Animals in Research: Reporting In-Vivo Experiments) and European Community 
Guidelines/ EEC Directive, 1986. This study was approved by the Faculty of Medicine, Animal Care and Use Committee (ACUC), University of Malaya with ethics number: 2013-07-15/FIS/R/NS. Toxicity study was conducted according to Organization for Economic Cooperation and Development (OECD) revised up-and-down procedure for acute toxicity testing (OECD guideline 425) [18]. No signs of toxicity were observed in the tested animals up to a dose of $3000 \mathrm{mg} / \mathrm{kg} /$ day.

\section{Induction of diabetes}

Hyperglycemia was induced in overnight fasted male rats by a single intraperitoneal injection of STZ dissolved in ice cold citrate buffer $(0.1 \mathrm{M}, \mathrm{pH} 4.5)$ at a dose of $55 \mathrm{mg} / \mathrm{kg}$ [19]. The rats were allowed to drink $5 \%$ sucrose solution overnight after injection, to overcome drug-induced hypoglycemia. Diabetes was confirmed by the presence of polydipsia, polyuria and weight loss and only animals exhibiting a fasting glucose level greater than $300 \mathrm{mg} / \mathrm{dL}$ three days after STZ injection were used in this study. Treatment with $C$. borivilianum was commenced four days after STZ injection and this was considered as day one. $C$. borivilianum root extract at 250 and $500 \mathrm{mg} / \mathrm{kg} / \mathrm{day}$ [20] were administered in the form of suspension in $1 \%$ sodium carboxymethylcellulose (Na-CMC) dissolved in distilled water daily for 28 consecutive days using an oral gavage tube.

\section{Experimental design}

The animals were randomly assigned into five experimental groups with six (6) rats per group:

Group I - Control rats- received 1\% Na-CMC vehicle only.

Group II - Diabetic control rats- received 1\% Na-CMC vehicle only.

Group III and IV - Diabetic rats treated with $C$.

borivilianum root aqueous extract at $250 \& 500 \mathrm{mg} / \mathrm{kg}$

body weight respectively.

Group V- Diabetic rats treated with standard antidiabetic agent, glibenclamide at $600 \mu \mathrm{g} / \mathrm{kg}$ body weight.

At the end of experimental period, all rats were fasted overnight, weighted and sacrificed under pentobarbital sodium anesthesia $(60 \mathrm{mg} / \mathrm{kg})$ followed by cervical dislocation.

\section{Determination of sperm characteristics and morphology}

Immediately after euthanasia, cauda epididymis were dissected out, chopped and placed in $5 \mathrm{ml}$ physiological saline $(0.9 \% \mathrm{NaCl})$ and incubated for $5 \mathrm{~min}$ at $37^{\circ} \mathrm{C}$ in water bath to allow sperm to leave the epididymal tubules.

\section{Evaluation of sperm forward motility}

Progressive sperm motility was evaluated by a method of Belsey et al. [21]. Firstly, immotile sperm were counted followed by motile sperm. Sperm forward motility was expressed as percentage of motile sperm to total sperm counted.

\section{Sperm count}

Sperm count was determined using Neubauer chamber (Deep 1/10 mm, LAMBART, Darmstadt, Germany) of hemocytometer following the method as described by Belsey et al. [21]. Sperm count was expressed as number of sperm per $\mathrm{ml}$ of solution.

\section{Sperm viability}

The ratio of live to dead sperm was determined using 1\% trypan blue staining following the method as described by Talbot and Chacon [22]. A total number of 200 sperm were counted per slide and the results were expressed as percentage of the live sperm.

\section{Hypo-osmotic Swelling Test (HOST)}

Sperm's flagella membrane integrity was assessed by hypo-osmotic swelling test (HOST). In brief, assay was performed by incubating $50 \mu \mathrm{L}$ sperm suspension with $1 \mathrm{~mL}$ hypo-osmotic solution. Two hundred sperm were evaluated and percentage of live sperm (with coiled tail) was calculated following the method of Jeyendran et al. [23].

\section{Sperm morphological abnormalities}

Percentages of sperm head, middle piece and tail abnormalities were determined from a total of 300 sperm per rat [24]. Sperm morphology was viewed under a light microscope (Nikon, H600L, Tokyo, Japan) under $400 \times$ magnifications. Data was expressed as percentage of morphologically abnormal sperm to total sperm count.

\section{Biochemical analyses}

Following analysis of sperm parameters, the remaining cauda epididymal sperm suspension was centrifuged at $800 \mathrm{~g}$ for $20 \mathrm{~min}$ at $4^{\circ} \mathrm{C}$ and the pellet was resuspended in normal saline. The sperm were homogenized with a glass-Teflon Homogenizer (Heidolph Silent Crusher M, Germany). The supernatant collected was used for biochemical studies.

\section{Assessment of sperm lipid peroxidation}

The lipid peroxidation level in sperm homogenate was measured as malondialdehyde (MDA), which is the end product of lipid peroxidation, which reacts with thiobarbituric acid (TBA) to produce TBA reactive substance (TBARS), a red colored complex which has peak 
absorbance at $532 \mathrm{~nm}$, according to the method of Ohkawa et al., [25].

\section{Determination of Hydrogen peroxide and nitric oxide level in sperm}

In the supernatant levels of $\mathrm{H}_{2} \mathrm{O}_{2}$ were estimated according to the method by Pick [26]. In brief, $\mathrm{H}_{2} \mathrm{O}_{2}$ mediates horseradish peroxidase-dependent oxidation of phenol red and the results obtained were expressed as nmol $\mathrm{H}_{2} \mathrm{O}_{2}$ formed $\mathrm{g}^{-1}$ tissue. Nitric oxide (NO) concentration was measured as nitrite/nitrate by previous method of Miranda et al., [27]. The NO levels were expressed as nmol/g tissue.

\section{Assessment of Sperm Total Antioxidant Capacity (TAC)}

The total antioxidant capacity of sperm homogenate was measured according to the modified method of Erel, [28], where the samples were mixed with acetate buffer, and 2,2'azino-bis(3-ethylbenzothiazoline-6-sulfonic acid) (ABTS reagent) with hydrogen peroxide. The color reaction was monitored spectrophotometrically at $660 \mathrm{~nm}$. The results were expressed as $\mu$ molequivalents Trolox/mg protein.

\section{Determination of sperm endogenous antioxidant enzyme activity}

SOD activity level was assayed according to the method by Misra and Fridovich [29] and was expressed as the amount of enzyme that inhibits oxidation of epinephrine by $50 \%$, which was equal to $1 \mathrm{U}$ per milligram of protein. CAT activity level was determined on the basis of $\mathrm{H}_{2} \mathrm{O}_{2}$ decomposition [30] and was expressed in $\mu \mathrm{mol}$ of $\mathrm{H}_{2} \mathrm{O}_{2}$ metabolized $/ \mathrm{mg}$ protein $/ \mathrm{min}$. Meanwhile, GPx activity level was determined according to the method by Rotruck et al. [31] and was expressed as $\mu \mathrm{mol}$ of GSH consumed/ $\mathrm{mg}$ protein/min.

\section{In-vitro radical scavenging activity of $C$. borivilianum root extract}

Antioxidant power of $C$. borivilianum root aqueous extract was evaluated by using DPPH, superoxide, hydroxyl, $\mathrm{H}_{2} \mathrm{O}_{2}$, NO and reducing power scavenging assays. Ascorbic acid $(10-200 \mu \mathrm{g} / \mathrm{ml})$ was used as a standard. The ability of extract to scavenge or inhibit free radicals was expressed as $\%$ inhibition and was calculated using this formula.

$$
\% \text { of inhibition }=\frac{\left(A_{0}-A_{t}\right)}{A_{0}} \times 100
$$

$A_{o}=$ absorbance of control group (without plant extract) and $\mathrm{A}_{\mathrm{t}}=$ absorbance of $C$. borivilianum root aqueous extract. Absorbance was measured using a spectrophotometer (UV-1700, Shimadzu, Kyoto, Japan) at different wavelengths depending on the type of assay performed. All assays were carried out in triplicate.
Radical-scavenging activity of $C$. borivilianum root aqueous extract against stable DPPH radical was determined according to the method by Katalinic et al., [32]. Measurement of superoxide radical scavenging activity was based on the method by Xiang and Ning [33]. Hydroxyl radical scavenging activity was measured using a modified method by Halliwell et al., [34]. The ability of $C$. borivilianum root aqueous extract to scavenge $\mathrm{H}_{2} \mathrm{O}_{2}$ was determined according to the method by Ruch et al., [35]. The ability of the extract to scavenge nitric oxide was determined using a method by Dastmalchi et al., [36]. Finally, reducing power scavenging activity of C. borivilianum root extract was determined according to the method by Suseela et al., [37].

\section{Estimation of sperm caspase-3 levels}

Snapped-frozen sperm were homogenized using a sonicator with PRO-PREP (iNtRON Biotechnology, Seoul, South Korea) extraction solution in the presence of protease inhibitors. Total cell protein was obtained by centrifugation at $13000 \mathrm{~g}$ for 15 minutes at $4^{\circ} \mathrm{C}$. After determination of the protein concentration, the same amount of protein was loaded into the $12 \%$ SDS-PAGE gel. The protein was then transferred onto the polyvinyilidene difluoride (PVDF) membrane and incubated in 5\% BSA for 90 minutes. The blot was then exposed to primary antibody, caspase-3 rabbit polyclonal IgG, Santa Cruz, USA (sc-7148) at 1:1000 dilution. Following primary antibody incubation, the blot was incubated with HRP-conjugated secondary antibody and finally visualized by using Optic 4C (Bio RAD). $\beta$-actin (Santa cruz, sc-130656) was used as a loading control. Photos of the blots were captured and density of each band was determined using Image J software (1.39, Bethesda, Maryland, USA). The ratio of caspase- $3 / \beta$-actin band density was determined and was considered the expression level of each of the target proteins.

\section{Determination of Serum HbA1c and Fasting Blood Glucose (FBG) Levels}

At the end of 28 day treatment, blood was withdrawn from retro-orbital plexus in overnight fasted diabetic rats. Glucose levels were estimated using glucose oxidase/peroxidase kit (BioSystems S.A. Costa Brava 30, Barcelona, Spain) and HbA1c was measured using a commercially available kit (BioSystems S.A. Costa Brava 30, Barcelona, Spain). The values were estimated using an automated analyzer Dimension RxL Max Integrated Chemistry System (Siemens Healthcare Diagnostics Inc. Deerfield, IL, USA).

\section{Epididymal sperm density}

Caput epididymis was freshly harvested and fixed in 10\% formaldehyde for 24 hours. The tissue was dehydrated in ethanol, cleared in xylene and embedded in paraffin at $58^{\circ} \mathrm{C}$. The embedded tissue samples were cut into $5 \mu \mathrm{m}$ 
thickness using a microtome (Histo-line laboratories, ARM-3600, Viabrembo, Milano, Italy). After deparaffinization by immersion into xylene for $20 \mathrm{~min}$, tissues were dropped in ethanol solution of decreasing concentrations (100\%, 95\%, 90\% and 80\%) for $5 \mathrm{~min}$. Sections were then stained with hematoxylin and eosin (H\&E). Sperm density in epididymal lumen was graded as normal $(+++)$, moderately decreased $(++)$, or severely decreased $(+)$ according to description by Narayana et al., [38].

\section{Statistical analysis}

Statistical differences were evaluated by analysis of variance (ANOVA) and Student's t-test. A probability level of less than $0.05(\mathrm{p}<0.05)$ was considered as significant. Post-hoc statistical power analysis was performed for all the experiments and values $>0.8$ were considered as adequate. Meanwhile, Shapiro-Wilk test was performed to test for data normality and values $>0.05$ indicated that data were normally distributed.

\section{Results}

\section{Phytochemical screening}

Qualitative phytochemical screening of aqueous extract of C. borivilianum root showed the presence of carbohydrates, proteins, phytosterols and saponins (data not shown).

\section{FTIR spectral analysis}

Figure 1 shows FTIR spectrum and Table 1 shows the active compounds present in the extract. FTIR spectroscopy is widely used technique in the characterization and identification of different solid-state forms. The FTIR spectra O-H (Asym str) of the compound observed at $3385.62 \mathrm{~cm}^{-1}$ and also $\mathrm{CH}_{2}=\mathrm{CH}$ - asymmetric stretching frequency of compound observed at $2929.67 \mathrm{~cm}^{-1}$. A weak band was observed at $1720 \mathrm{~cm}^{-1}$ indicating that the compound may contain $-\mathrm{C}=\mathrm{O}$ stretching frequency. Aromatic $-\mathrm{C}=\mathrm{C}($ Str $)$ peaks are resonating at 1414, 1513, $1632,1640 \mathrm{~cm}^{-1}$. Secondary alcohol C-O stretching frequencies of the compound were observed at $1151 \mathrm{~cm}^{-1}$. A strong band of aromatic ether linkage was observed at $1028 \mathrm{~cm}^{-1}$ indicating that the compound contained C-O-C functional group and $706-773 \mathrm{~cm}^{-1}$ indicating that the compound might be mono substituted.

\section{Effect on sperm characteristics}

Table 2 shows the effect of treatment of $C$. borivilianum root extract on sperm characteristics in diabetic rats. Our findings indicate that in diabetic rats, sperm count was $41.67 \%$ lower than normal, non-diabetic rats. In diabetic rats, total sperm count was approximately $45.87 \pm 6.87 \mathrm{million} / \mathrm{ml}$ which was lesser than the normal count. 28-days treatment with the root extract of C. borivilianum at 250 and $500 \mathrm{mg} / \mathrm{kg} /$ day caused a significantly higher count $(34.46 \%$ and $49.64 \%$ respectively) as compared to non-treated diabetic rats. Glibenclamide treatment resulted in 51.55\% higher count as compared to non-treated diabetic rats. No significant difference in the count was noted between treatment with $500 \mathrm{mg} / \mathrm{kg} /$ day $C$. borivilianum and glibenclamide.

Meanwhile, sperm motility in diabetic rats was $40.78 \%$ lower than normal non-diabetic rats. 28-days treatment with $C$. borivilianum root extract resulted in a significantly higher progressive sperm motility $(34.50 \%$ and $56.75 \%$ respectively) as compared to non-treated diabetic rats. Treatment with $600 \mu \mathrm{g} / \mathrm{kg} /$ day glibenclamide resulted in $59.52 \%$ higher progressive sperm motility as compared to non-treated diabetic rats. Glibenclamide was 1.73 times more potent than $250 \mathrm{mg} / \mathrm{kg} /$ day $C$. borivilianum root

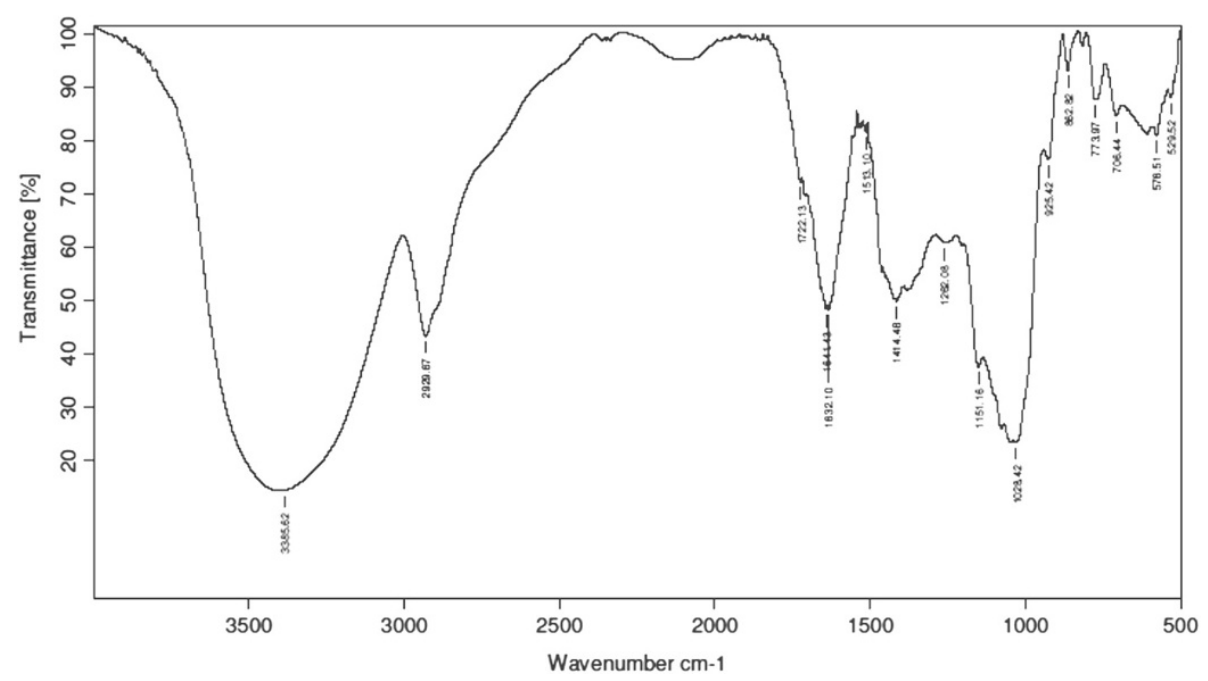

Figure 1 FTIR spectrum of aqueous extract of $\boldsymbol{C}$. borivilianum root. A broad trough is seen at $3385.62 \mathrm{~cm}^{-1}$. 
Table 1 FTIR peak values of extracts of $C$. borivilianum root extract

\begin{tabular}{lll}
\hline S. No & Area & Name of the group \\
\hline 1 & $3385.62 \mathrm{~cm}^{-1}$ (broad trough ) & Alcohol/Phenol (High concentration)
\end{tabular}
$2929.67 \mathrm{~cm}^{-1}$ (medium-strong ) $\quad \mathrm{CH}_{2}=\mathrm{CH}$

Methylene

$3 \quad 1722.13 \mathrm{~cm}^{-1}$ (weak band)<smiles>COc1ccccc1</smiles>

Saturated aliphatic/cyclic 6-membered

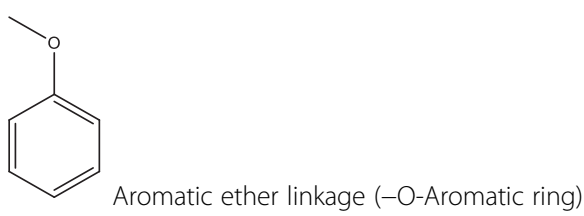

Aromatic ether linkage (phenol derivative)<smiles>CC(C)O</smiles>

Alcohol

$7 \quad 1028 \mathrm{~cm}^{-1}$ (strong band)<smiles>COC</smiles>

Aromatic ether linkage

Aromatic ether stretching frequency

$8 \quad 706-773 \mathrm{~cm}^{-1}$

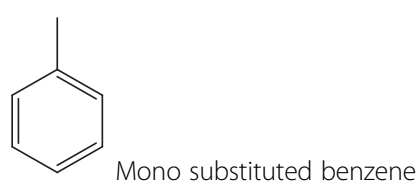

Mono substituted aromatic ring

Table 2 Effect of $C$. borivilianum root extract on sperm parameters

\begin{tabular}{llllll}
\hline Parameters & Normal & Diabetic & Diabetic & & \\
\cline { 4 - 6 } & & & $\mathbf{2 5 0} \mathbf{~ m g / k g ~ C . ~ b o r i v i l i a n u m ~}$ & $\mathbf{5 0 0} \mathbf{~ m g / k g ~ C . ~ b o r i v i l i a n u m ~}$ & $\mathbf{6 0 0} \boldsymbol{\mu g} / \mathbf{k g ~ g l i b e n c l a m i d e}$ \\
\hline Sperm count (millions/ml) & $78.64 \pm 6.74$ & $45.87^{*} \pm 6.87$ & $61.68^{\dagger} \pm 5.86$ & $68.64^{\dagger} \pm 5.68$ & $69.52^{\dagger} \pm 5.71$ \\
Sperm motility (\%) & $73.76 \pm 5.84$ & $43.68^{*} \pm 6.79$ & $58.75^{\dagger} \pm 4.38$ & $68.47^{\dagger} \pm 5.76$ & $69.68^{\dagger} \pm 5.61$ \\
Sperm viability (\%) & $82.69 \pm 4.47$ & $62.87^{*} \pm 3.86$ & $71.34^{\dagger} \pm 4.79$ & $73.35^{\dagger} \pm 4.08$ & $75.38^{\dagger} \pm 5.35$ \\
HOS tail coiled sperm (\%) & $69.58 \pm 3.64$ & $43.27^{*} \pm 3.78$ & $54.86^{\dagger} \pm 4.37$ & $61.78^{\dagger} \pm 3.61$ & $62.42^{\dagger} \pm 4.13$
\end{tabular}

Values are expressed as Mean \pm SD of 6 rats, $n=6$ per treatment group. ${ }^{*} \mathrm{p}<0.01$ as compared to control, ${ }^{\dagger} \mathrm{p}<0.05$ as compared to non-treated diabetic rats. 
extract in causing an increase in sperm progressive (forward) motility in diabetic rats.

The sperm viability was $23.97 \%$ lower in diabetic rats than normal, non-diabetic rats. 28-days treatment with $C$. borivilianum root extract resulted in a significantly higher viability (13.47 and $16.67 \%$ respectively) as compared to non-treated diabetic rats. Meanwhile, treatment with glibenclamide resulted in $19.9 \%$ higher viability as compared to non-treated diabetic rats. Glibenclamide treatment was 1.48 times more potent than $250 \mathrm{mg} / \mathrm{kg} /$ day C. borivilianum root extract in causing increased in sperm viability in diabetic rats.

The HOS tail coiled sperm was $37.82 \%$ lower in diabetic rats than normal, non-diabetic rats. 28-days treatment with 250 and $500 \mathrm{mg} / \mathrm{kg} /$ day C. borivilianum root extracts resulted in $26.79 \%$ and $42.87 \%$ higher HOS tail-coiled sperm respectively as compared to non-treated diabetic rats. Treatment with glibenclamide resulted in $44.26 \%$ higher HOS tail-coiled sperm as compared to non-treated diabetic rats. Glibenclamide treatment was 1.65 times more potent than $250 \mathrm{mg} / \mathrm{kg} /$ day C. borivilianum in causing increased percentage of HOS tail coiled sperm in diabetic rats.

\section{Effect on sperm morphology and percentages of abnormal sperm}

Figure 2 shows percentages of abnormal sperm in various treatment groups while Figure 3 shows various sperm morphologies observed in normal, non-diabetic and diabetic male rats. The percentage of abnormal sperm in diabetic rats was $1614.15 \%$ higher than in normal, non-diabetic rats. 28-days treatment with 250 and $500 \mathrm{mg} / \mathrm{kg} /$ day C. borivilianum root extracts resulted in $39.76 \%$ and $50.35 \%$ lower abnormal sperm percentages respectively as compared to the non-treated diabetic rats. Treatment with glibenclamide resulted in 53.09\% lower abnormal sperm percentage as compared to non-treated diabetic rats. Glibenclamide treatment was 1.35 times more potent than $250 \mathrm{mg} / \mathrm{kg} /$ day C. borivilianum in causing decreased in percentage of abnormal sperm in diabetic rats.

The abnormal sperm morphologies include small hook, thin elongate head, rod head, banana head, bent neck, pin head and macro cephalous (Figure 3). In Table 3, the percentage of each of these abnormal-shaped sperm was shown. Our findings indicate that a significantly higher percentage of pin head and bent neck sperm were observed in diabetic rats, (8.01 and 2.05 times higher respectively) as compared to normal non-diabetic rats. Other sperm shapes such as banana head, rod head, small hook, thin elongated and macro-cephalous were only seen in diabetic rats and not in normal non-diabetic rats. Meanwhile, in diabetic rats, the highest percentage of abnormal shaped sperm is banana head, which accounts for nearly $13.2 \%$ followed by rod head, pin head, small

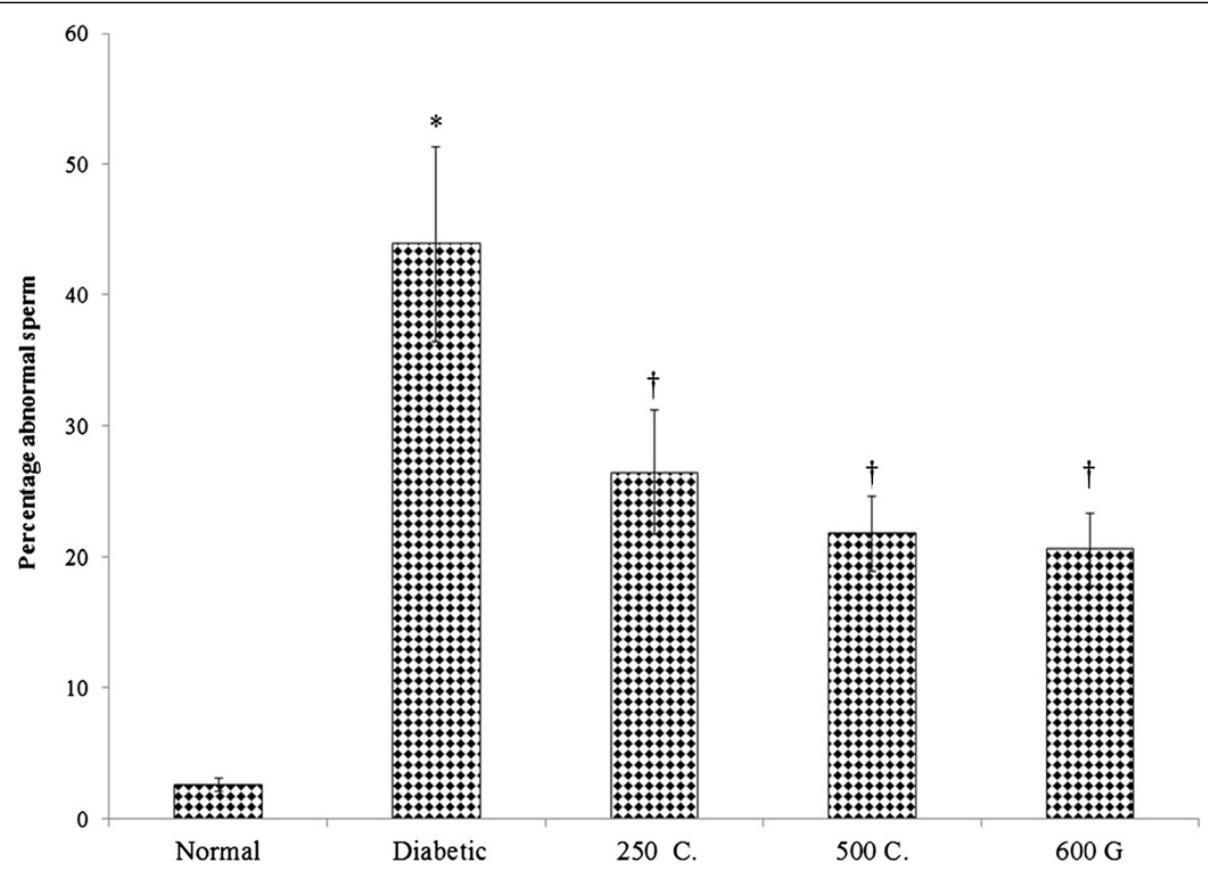

Figure 2 Percentage of abnormal sperm in different experimental groups. A significantly higher abnormal sperm percentage was observed in diabetic rats. Treatment with C. borivilianum root extract at both doses or glibenclamide lower the percentage of abnormal sperm as compared to non-treated diabetic rats. ${ }^{*} \mathrm{p}<0.05$ as compared to normal (control), ${ }^{\dagger} \mathrm{p}<0.01$ as compared to diabetic group. $\mathrm{n}=6$ rats per group. $250 \mathrm{C}$ : 250 mg/kg/day C. borivilianum extract, 500C: 500 mg/kg/day C. borivilianum extract, 600G: 600 mg/kg/day glibenclamide. 

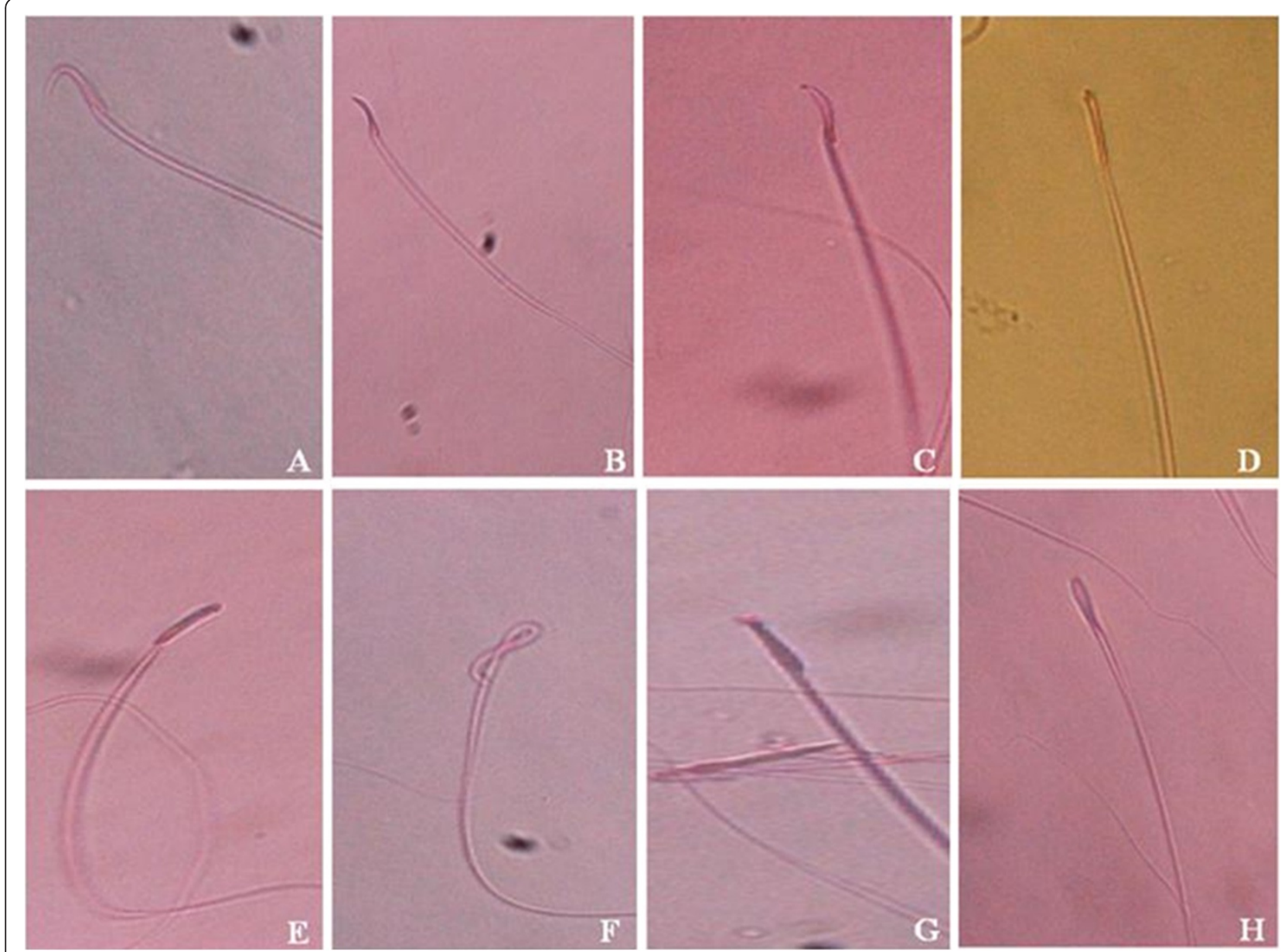

Figure 3 Appearance of abnormal sperm. Various abnormal sperm shapes are observed under a light microscope in normal, diabetic rats and diabetic rats treated with C. borivilianum or glibenclamide which include $\mathbf{A}$ ) Normal $\mathbf{B}$ ) small hook $\mathbf{C}$ ) thin elongated head $\mathbf{D})$ rod head $\mathbf{E}$ ) banana head $\mathbf{F}$ ) bent neck $\mathbf{G}$ ) pin head $\mathbf{H}$ ) macro cephalous; Stained with eosin-nigrosin, $100 \times$ magnification.

hook, bent neck, thin elongated and macro-cephalous. Treatments with C. borivilianum root extract at 250 and $500 \mathrm{mg} / \mathrm{kg} /$ day to diabetic rats significantly lowered the percentage of abnormal-shaped sperm. Treatment with $500 \mathrm{mg} / \mathrm{kg} /$ day C. borivilianum caused $87.59 \%, 82.08 \%$, $77.95 \%, 75.82 \%, 58.53 \%, 44.15 \%$ and $42.81 \%$ lower in percentages of macrocephalous, thin elongated, rod head, bent neck, small hook, pin head and banana head sperm respectively as compared to non-treated diabetic rats. Glibenclamide treatment caused a significantly lower percentage of rod head and macro cephalic sperm as compared to treatment with $C$. borivilianum root extract however no significant different in percentages were noted between pin head and bent neck sperm in non-treated diabetic rats.

Table 3 Percentage of different types of abnormal sperm in different experimental groups

\begin{tabular}{lccccc}
\hline Parameters & Normal & Diabetic & \multicolumn{3}{c}{ Diabetic } \\
\cline { 3 - 6 } & & & $\mathbf{2 5 0} \mathbf{~ m g / k g ~ C . ~ b o r i v i l i a n u m ~}$ & $\mathbf{5 0 0} \mathbf{~ m g / k g ~ C . ~ b o r i v i l i a n u m ~}$ & $\mathbf{6 0 0} \boldsymbol{~} \mathbf{g} / \mathbf{k g}$ glibenclamide \\
\hline Pin-head sperm & $1.03 \pm 0.02$ & $8.63^{*} \pm 1.05$ & $5.78^{\dagger} \pm 0.26$ & $4.82^{\dagger} \pm 1.09$ & $8.35^{\dagger} \pm 1.06$ \\
Banana-head sperm & - & $13.15 \pm 2.24$ & $8.65 \pm 1.09$ & $7.52 \pm 1.05$ & $5.89 \pm 0.85$ \\
Rod less sperm & - & $9.84 \pm 1.34$ & $3.16 \pm 0.22$ & $2.17 \pm 0.07$ & $3.53 \pm 0.16$ \\
Pin less sperm & - & $6.39 \pm 1.58$ & $2.85 \pm 0.11$ & $2.65 \pm 0.04$ & $5.18 \pm 0.27$ \\
Folded tail sperm & $1.53 \pm 0.03$ & $3.35^{*} \pm 0.37$ & $2.59^{\dagger} \pm 0.06$ & $0.81^{\dagger} \pm 0.06$ & $3.66^{\dagger} \pm 0.34$ \\
Other shaped sperm & - & $1.15 \pm 0.18$ & $1.25 \pm 0.05$ & $1.34 \pm 0.05$ & $2.08 \pm 0.05$ \\
\hline
\end{tabular}

Values are expressed as Mean \pm SD of 6 rats, $n=6$ per treatment group. ${ }^{*} p<0.01$ as compared to control, ${ }^{\dagger} p<0.05$ as compared to non-treated diabetic rats. 


\section{Effect on sperm MDA content}

Figure 4 shows the amount of MDA in sperm which was the highest in diabetic rats (171.27\%) as compared to normal, non-diabetic rats. Treatment with 250 and $500 \mathrm{mg} / \mathrm{kg} /$ day root extract of C. borivilianum resulted in $24.44 \%$ and $41.96 \%$ decrease in MDA content respectively as compared to non-treated diabetic rats. Meanwhile glibenclamide treatment resulted in $45.94 \%$ decrease in sperm MDA content as compared to nontreated diabetic rats.

\section{Effect on hydrogen peroxide and nitric oxide level in sperm} Figure 5 shows the (A) hydrogen peroxide and (B) nitric oxide levels in sperm which were highest in diabetic rats. Administration of $C$. borivilianum root extract at 250 and $500 \mathrm{mg} / \mathrm{kg} /$ day resulted in decreased level of both free radicals. Similar effect was observed following administration of glibenclamide.

\section{Effect on Sperm Total Antioxidant Capacity (TAC)}

Figure 6 shows sperm TAC level which was the highest in normal, non-diabetic rats. The TAC level in diabetic rats was $42.76 \%$ lower than normal, non-diabetic rats. Treatment with 250 and $500 \mathrm{mg} / \mathrm{kg} /$ day aqueous root extract of C. borivilianum resulted in $21.56 \%$ and $37.16 \%$ higher TAC level as compared to non-treated diabetic rats. Meanwhile, glibenclamide treatment resulted in 50.19\% higher TAC level as compared to non-treated diabetic rats.

\section{Effect of $C$. borivilianum on sperm endogenous antioxidant enzymes}

In Table 4, SOD, CAT and GPx activity levels were lowest in diabetic rats. Treatment with 250 and $500 \mathrm{mg} / \mathrm{kg} /$ day $C$. borivilianum root aqueous extract resulted in a significantly higher activity levels of SOD, CAT and GPx as compared to non-treated diabetic rats. Similarly, GPx activity level following the root extract treatment was significantly greater than non-treated diabetic rats.

\section{In-vitro free radical scavenging activity of $C$. borivilianum root extract}

In Figure 7(A), inhibition of DPPH radicals by $10 \mu \mathrm{g} / \mathrm{ml}$ C. borivilianum root extract was $18.36 \%$ while for ascorbic acid was $29.65 \%$. $\mathrm{IC}_{50}$ for C. borivilianum root extract and ascorbic acid were $34.76 \mu \mathrm{g} / \mathrm{ml}$ and $28.47 \mu \mathrm{g} / \mathrm{ml}$ respectively. The $\mathrm{IC}_{50}$ for the root extract was 1.22 fold lower than ascorbic acid. Both standard and extract recorded a gradual dose-dependent increase in DPHH radicals inhibition. Figure 7(B) shows the superoxide radical scavenging activity of the root extract of C. borivilianum and ascorbic acid which indicate a dose-dependent increase. The percentage inhibition by $10 \mu \mathrm{g} / \mathrm{ml} \mathrm{C}$. borivilianum root extract and ascorbic acid were $6.68 \%$ and $25.87 \%$

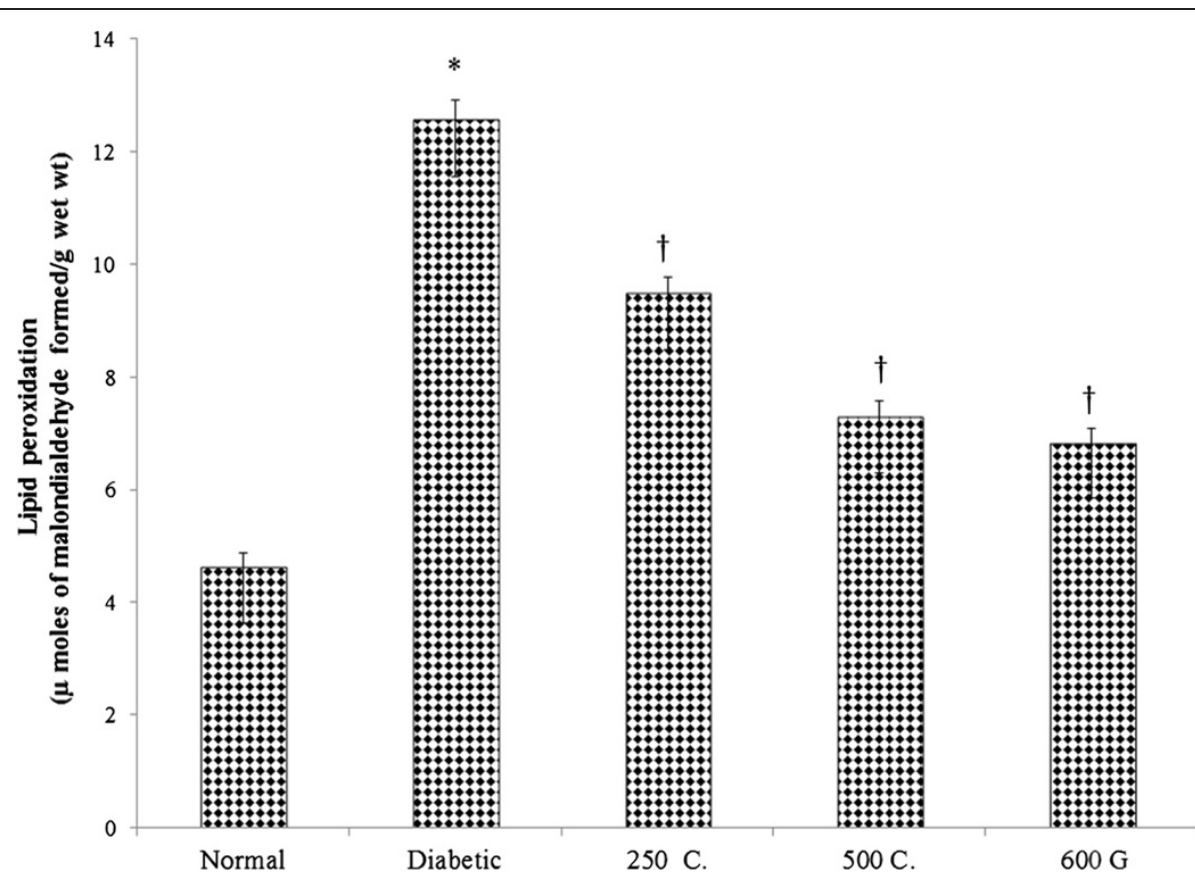

Figure 4 Sperm MDA content. Higher MDA level was noted in diabetic rats as compared to normal, non-diabetic rats. Administration of $C$. borivilianum root extract resulted in decreased MDA level. 250C: $250 \mathrm{mg} / \mathrm{kg} / \mathrm{day}$ C. borivilianum root extract; 500C: 500 mg/kg/day C. borivilianum root extract, 600G: $600 \mathrm{\mu g} / \mathrm{kg} /$ day glibenclamide. $\mathrm{n}=6$ per treatment group, ${ }^{*} \mathrm{p}<0.05$ as compared to normal, non-diabetic control rats, ${ }^{\dagger} \mathrm{p}<0.05$ as compared to non-treated diabetic rats. 

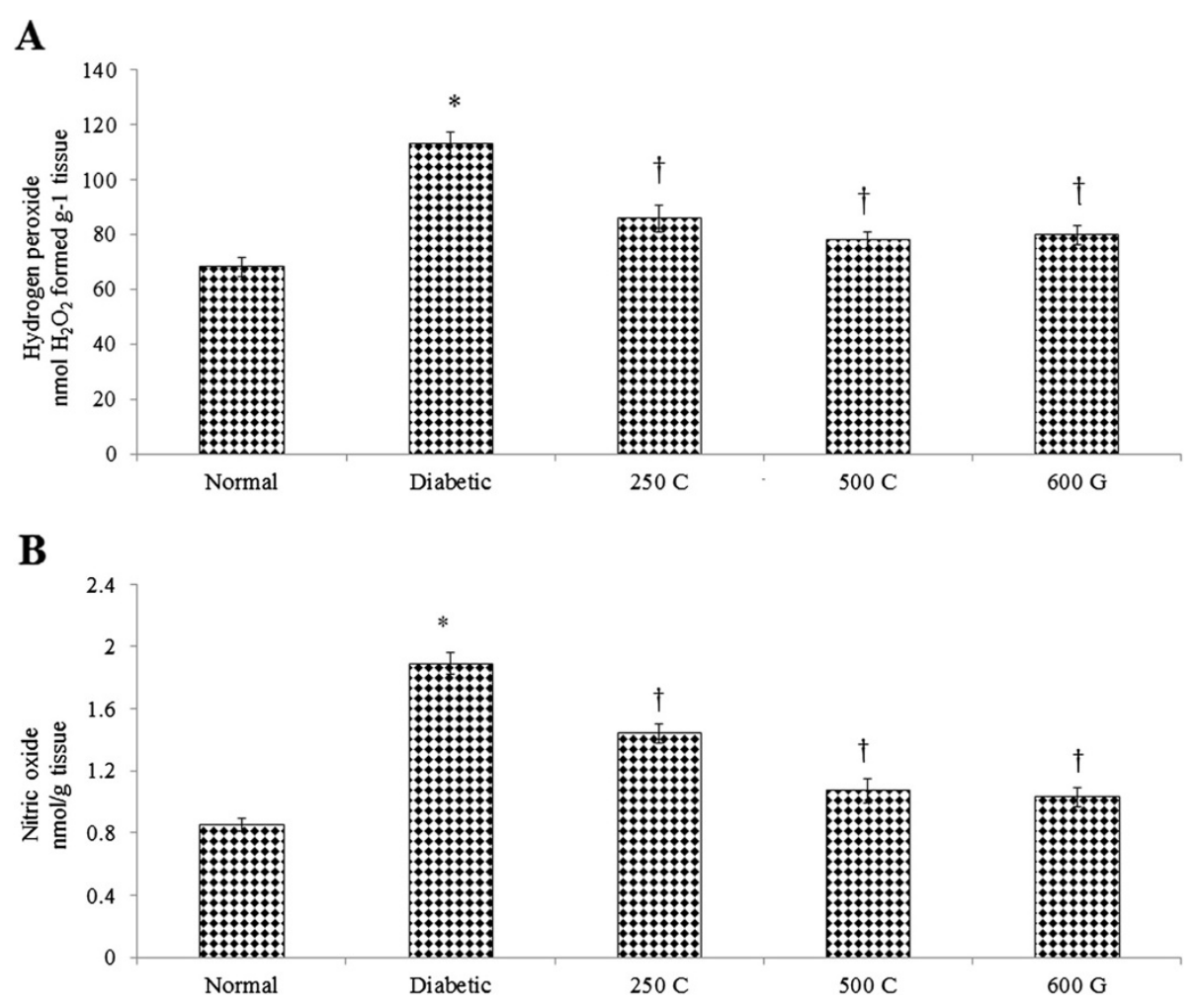

Figure 5 Sperm $\mathrm{H}_{2} \mathrm{O}_{2}$ and $\mathrm{NO}$ levels. Higher (A) $\mathrm{H}_{2} \mathrm{O}_{2}$ and (B) $\mathrm{NO}$ levels were observed in diabetic rats as compared to normal, non-diabetic rats. Administration of C. borivilianum root extract resulted in decreased $\mathrm{H}_{2} \mathrm{O}_{2}$ and NO levels. 250C: $250 \mathrm{mg} / \mathrm{kg} /$ day C. borivilianum root extract; 500C: 500 mg/kg/day C. borivilianum root extract, 600G: $600 \mu \mathrm{g} / \mathrm{kg} /$ day glibenclamide. $\mathrm{n}=6$ per treatment group, ${ }^{*} \mathrm{p}<0.05$ as compared to normal, non-diabetic control rats, ${ }^{\dagger} p<0.05$ as compared to non-treated diabetic rats.

respectively. $\mathrm{IC}_{50}$ for $C$. borivilianum root extract was $75.45 \mu \mathrm{g} / \mathrm{ml}$ while for standard ascorbic acid was $28.58 \mu \mathrm{g} / \mathrm{ml}$. The $\mathrm{IC}_{50}$ for the root extract was 2.64 fold lower than ascorbic acid. Superoxide anion is a reduced form of molecular oxygen, which plays an important role in the formation of reactive oxygen species (ROS) including $\mathrm{H}_{2} \mathrm{O}_{2}$, hydroxyl radical or singlet oxygen [39].

Figure $7(\mathrm{C})$ shows dose-response curve for hydroxyl radical scavenging activity of the root extract of $C$. borivilianum and ascorbic acid. $\mathrm{IC}_{50}$ for $C$. borivilianum root extract was $44.92 \mu \mathrm{g} / \mathrm{ml}$ while for ascorbic acid was 31.87 $\mu \mathrm{g} / \mathrm{ml}$. The $\mathrm{IC}_{50}$ for the root extract was 1.41 times lower than ascorbic acid. Hydroxyl radical is a major active oxygen species formed in the biological system with capability to conjugate with nucleotides in the DNA resulting in strand breakage which could lead to various diseases. Moreover, hydroxyl radical is one of the rapid initiator of lipid peroxidation process via extracting hydrogen atom from the unsaturated fatty acids [40]. Figure 7(D) illustrates a dose-dependent increase in $\mathrm{H}_{2} \mathrm{O}_{2}$ scavenging activity of C. borivilianum root extract and ascorbic acid. $\mathrm{IC}_{50}$ of the root extract of $C$. borivilianum was $51.82 \mu \mathrm{g} / \mathrm{ml}$ while for ascorbic acid was $32.86 \mu \mathrm{g} / \mathrm{ml}$. The $\mathrm{IC}_{50}$ for ascorbic acid was higher than the root extract by 1.58 times. $\mathrm{H}_{2} \mathrm{O}_{2}$ is a weak oxidizing agent that directly inactivates few enzymes via oxidation of essential thiol $(-\mathrm{SH})$ group. This molecule could rapidly transverses the cell membrane. Once within the cell, $\mathrm{H}_{2} \mathrm{O}_{2}$ can react with $\mathrm{Fe}^{2+}$ and /or $\mathrm{Cu}^{2+}$ to form hydroxyl radical [41].

Our results showing nitric oxide scavenging activity of C. borivilianum root extract and ascorbic acid standard are presented in Figure 7(E). The root extract of C. borivilianum root exhibits a dose-dependent increase on nitric oxide scavenging activity. $\mathrm{IC}_{50}$ for the root extract and ascorbic acid were $65.32 \mu \mathrm{g} / \mathrm{ml}$ and $31.45 \mu \mathrm{g} / \mathrm{ml}$, respectively. $\mathrm{IC}_{50}$ of $C$. borivilianum root extract was lower than ascorbic acid by 2.08 times. NO is a free radical with a single unpaired electron, formed from L-arginine by the action of NO synthase [42]. In the present study, the root extract of $C$. borivilianum showed a significant radical scavenging effect on nitric oxide. Finally, the reducing power scavenging activity of the root extract and ascorbic acid are shown in Figure 7(F). At $10 \mu \mathrm{g} / \mathrm{ml}$, the percentage inhibition of $C$. borivilianum root extract and ascorbic acid were $32.68 \%$ and $38.67 \%$ respectively. $\mathrm{IC}_{50}$ of the root extract was $18.46 \mu \mathrm{g} / \mathrm{ml}$ while that of ascorbic acid was 13.54 $\mu \mathrm{g} / \mathrm{ml}$. Reducing power $\mathrm{IC}_{50}$ of $C$. borivilianum root extract was lower than ascorbic acid by 1.36 times. 


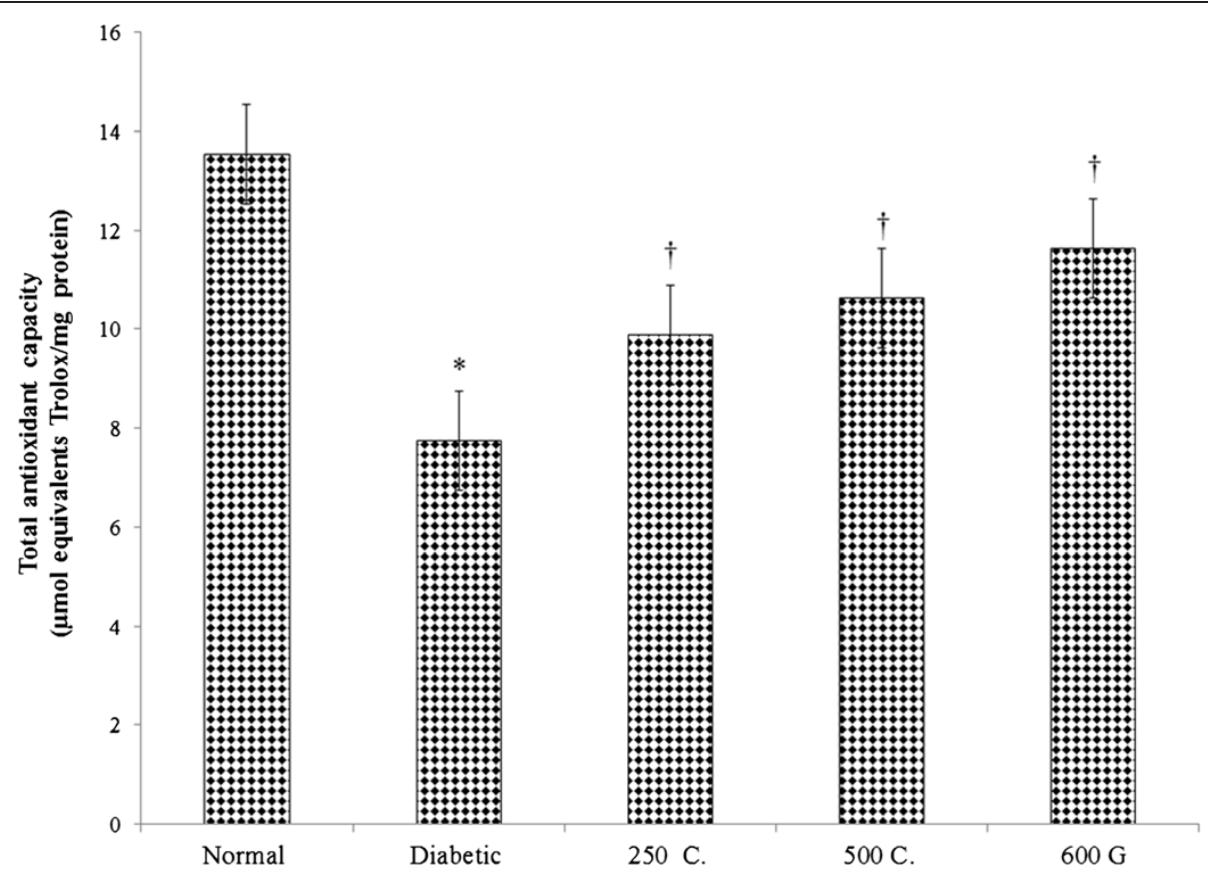

Figure 6 Sperm total antioxidant capacity (TAC). TAC was reduced in diabetic rats as compared to normal, non-diabetic rats. Administration of C. borivilianum root extract at 250 and $500 \mathrm{mg} / \mathrm{kg} /$ day and glibenclamide in diabetic rats resulted in higher TAC as compared to non-treated

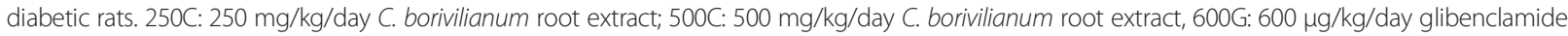
$\mathrm{n}=6$ per treatment group, ${ }^{*} \mathrm{p}<0.05$ as compared to normal, non-diabetic control rats, $\mathrm{t} p<0.05$ as compared to non-treated diabetic rats.

\section{Fasting blood glucose and serum HbA1c levels}

Table 5 shows treatment with $C$. borivilianum root extract at 250 and $500 \mathrm{mg} / \mathrm{kg} /$ day resulted in $44.5 \%$ and $49.2 \%$ lower serum FBG and $28.25 \%$ and $45.42 \%$ lower serum HbA1c levels respectively as compared to non-treated diabetic rats.

\section{Epididymal sperm density assessment}

Figure 8 shows appearance of epididymal lumen at high and low magnifications in normal non-diabetic, diabetic and diabetic rats treated with different doses of $C$. borivilianum root extract or glibenclamide while Table 6 shows semi-quantitative analysis of sperm density in the epididymal lumens. The highest density was seen in normal, nondiabetic rats. Meanwhile, low sperm density was seen in epididymal lumen of diabetic rats. Some of the lumens were completely devoid of sperm. An increased density was observed following treatment with increasing doses of C. borivilianum extract or glibenclamide as compared to non-treated diabetic rats.

\section{Caspase-3 level in sperm homogenates}

Figure 9 shows the effect of $C$. borivilianum aqueous root extract treatment on caspase- 3 expression in sperm which was significantly reduced as compared to nontreated diabetic rats. Similarly, glibenclamide administration resulted in a parallel decrease in caspase- 3 level of expression.

\section{Discussion}

To the best of our knowledge, this study reported for the first time the effect of root extract of C. borivilianum on sperm characteristics and oxidative stress in diabetic rats. Higher sperm count, percentages of sperm forward

Table 4 Effect of C. borivilianum on SOD, CAT and GPx levels in the sperm of different experimental groups

\begin{tabular}{|c|c|c|c|c|c|}
\hline \multirow[t]{2}{*}{ Parameters } & \multirow[t]{2}{*}{ Normal } & \multirow[t]{2}{*}{ Diabetic } & \multicolumn{3}{|c|}{ Diabetic } \\
\hline & & & $250 \mathrm{mg} / \mathrm{kg} \mathrm{C.} \mathrm{borivilianum}$ & $500 \mathrm{mg} / \mathrm{kg} \mathrm{C.} \mathrm{borivilianum}$ & $600 \mu \mathrm{g} / \mathrm{kg}$ glibenclamide \\
\hline $\begin{array}{l}\text { Superoxide dismutase (units/mg } \\
\text { protein/min) }\end{array}$ & $1.56 \pm 0.06$ & $0.95^{*} \pm 0.07$ & $1.26^{\dagger} \pm 0.08$ & $1.42^{\dagger} \pm 0.06$ & $1.45^{\dagger} \pm 0.07$ \\
\hline $\begin{array}{l}\text { Catalase }\left(\mathrm{H}_{2} \mathrm{O}_{2} \text { metabolized/mg }\right. \\
\text { protein/min) }\end{array}$ & $0.64 \pm 0.06$ & $0.34^{*} \pm 0.08$ & $0.45^{\dagger} \pm 0.06$ & $0.52^{\dagger} \pm 0.05$ & $0.56^{\dagger} \pm 0.07$ \\
\hline $\begin{array}{l}\text { Glutathione peroxidase ( } \mu \mathrm{mol} \text { of } \\
\text { GSH consumed/ mg protein/min) }\end{array}$ & $1.72 \pm 0.05$ & $1.26^{*} \pm 0.08$ & $1.57^{\dagger} \pm 0.05$ & $1.64^{\dagger} \pm 0.06$ & $1.66^{\dagger} \pm 0.07$ \\
\hline
\end{tabular}

The value represents means \pm S.D. for 6 rats per group. ${ }^{*} \mathrm{p}<0.01$ compared to normal, non-diabetic rats, ${ }^{\dagger} \mathrm{p}<0.01$ as compared to non-treated diabetic rats. 


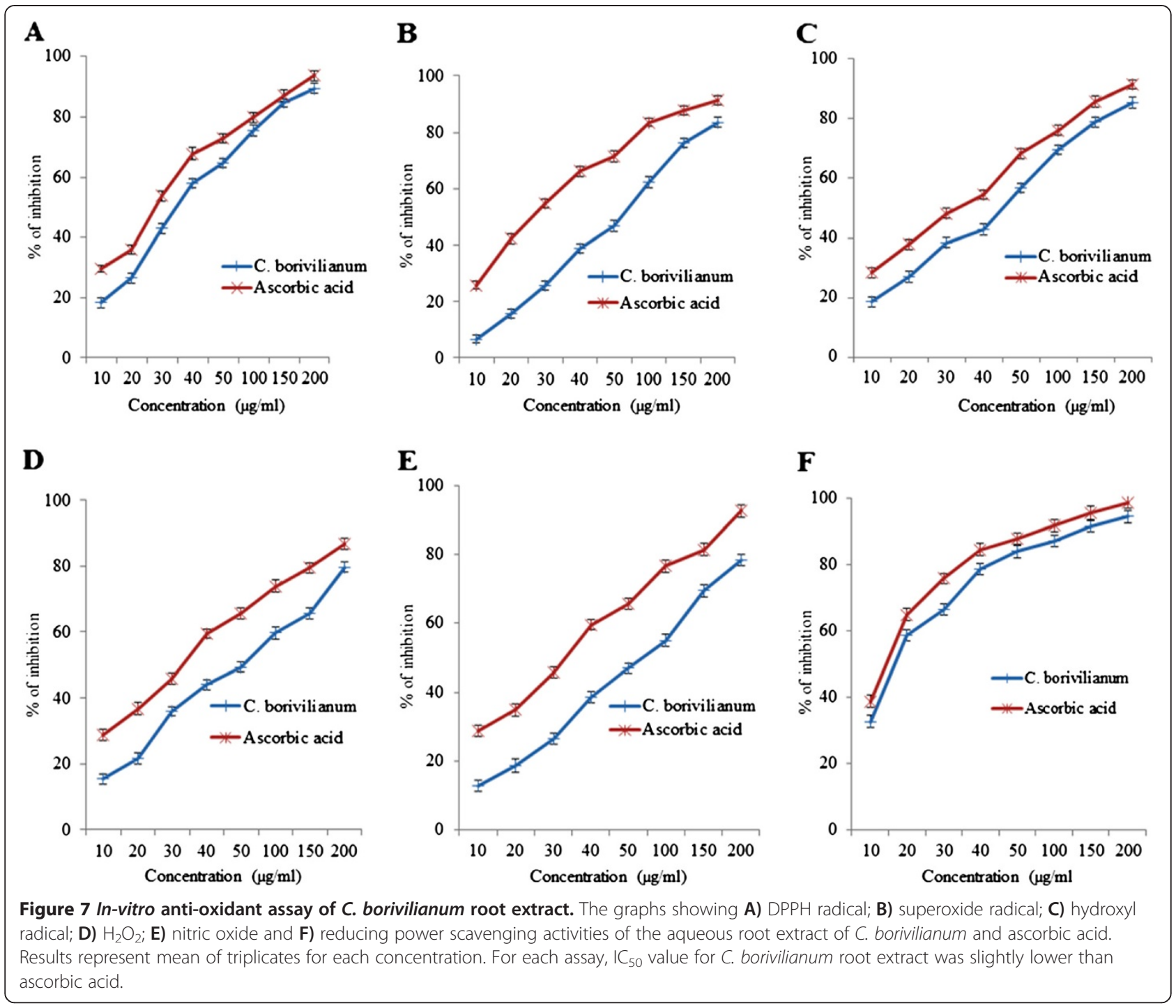

motility, viability and HOS tail-coiled with lower percentage of abnormal sperm were observed following $C$. borivilianum root extract treatment to STZ-induced diabetic rats. Administration of the root extract also lower the percentage of sperm with abnormal appearances, and in few occasion, the herbal root extract effect exceeds glibenclamide, a reference anti-diabetic drug [43]. Our findings have further shown that $C$. borivilianum root extract was able to lower the level of sperm oxidative stress as evident from lower amount of lipid peroxidation product, MDA, tissue superoxide and nitric oxide free radicals and higher amount of total antioxidant capacity (TAC) and levels of endogenous antioxidant enzymes (SOD, CAT and GPx) in the sperm of diabetic

Table 5 FBG and serum HbA1c levels in different experimental groups

\begin{tabular}{|c|c|c|c|c|c|}
\hline \multirow[t]{2}{*}{ Parameters } & \multirow[t]{2}{*}{ Normal } & \multirow[t]{2}{*}{ Diabetic } & \multicolumn{3}{|c|}{ Diabetic } \\
\hline & & & $250 \mathrm{mg} / \mathrm{kg} \mathrm{C.} \mathrm{borivilianum}$ & $500 \mathrm{mg} / \mathrm{kg} \mathrm{C.} \mathrm{borivilianum}$ & $600 \mu \mathrm{g} / \mathrm{kg}$ glibenclamide \\
\hline $\begin{array}{l}\text { Fasting blood glucose } \\
\text { levels (mg/dl) }\end{array}$ & $93.15 \pm 6.78$ & $424.16^{*} \pm 7.23$ & $235.24^{\dagger} \pm 6.78$ & $216.73^{\dagger} \pm 4.84$ & $203.68^{\dagger} \pm 8.46$ \\
\hline $\begin{array}{l}\text { Glycosylated hemoglobin, } \\
\text { HbA1c (\%) }\end{array}$ & $3.46 \pm 0.39$ & $9.38^{*} \pm 0.72$ & $6.73^{\dagger} \pm 0.61$ & $5.17^{\dagger} \pm 0.56$ & $5.12^{\dagger} \pm 0.43$ \\
\hline
\end{tabular}

Values are expressed as Mean \pm SD of 6 rats, $n=6$ per treatment group. ${ }^{*} \mathrm{p}<0.01$ as compared to control, $+\mathrm{p}<0.05$ as compared to non-treated diabetic rats. 

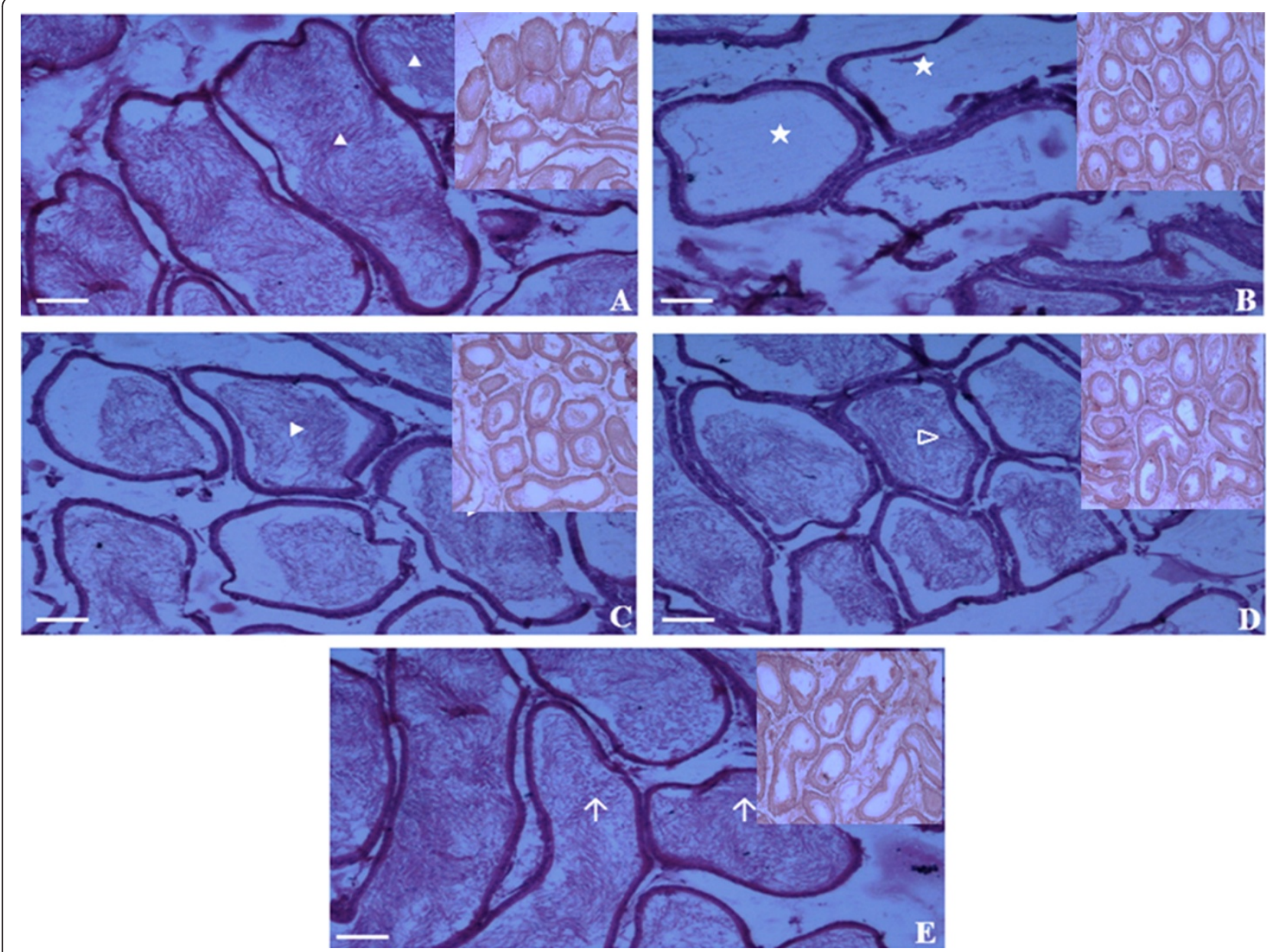

Figure 8 Morphology of epididymal lumen. Cross-sections of caput epididymis under high power field $(100 \times)$ and under low power field $(20 \times)$ (upper right hand border) in (A) normal, (B) STZ-induced diabetic rats (C) diabetic rats treated with $250 \mathrm{mg} / \mathrm{kg} /$ day C. borivilianum extract (D) diabetic rats treated with $500 \mathrm{mg} / \mathrm{kg} /$ day C. borivilianum extract (D) and (E) glibenclamide. Images showed that most tubules in STZ-induced diabetic rats were devoid of sperm with the tubules appearing smaller in size. Treatment with C. borivilianum root extract resulted in higher sperm density and size of the tubular lumens.

rats. Treatment with $C$. borivilianum root extract also prevents the increase in serum level of FBG and HbA1c in diabetic rats where this might help to prevent negative effects of hyperglycemia on sperm.

An evaluation of sperm characteristics is useful when investigating the underlying cause of male infertility [44]. In the present study, C. borivilianum root extract administration to diabetic rats prevented or reduced impairment in sperm characteristics, abnormal sperm percentages and abnormal appearances of sperm. The effect of diabetes on these sperm end point parameters was consistent with other reports in both rats and humans [45-47]. In diabetic rats, average sperm count of approximately $45 \mathrm{million} / \mathrm{ml}$ was lower than normal (approximately 60 milllion $/ \mathrm{ml}$ per ejaculate) $[19,48,49]$. Oligozoospermia could predispose diabetic males to subfertility or infertility [50]. The observed decrease in sperm count was supported by diminished sperm intensity in the epididymal lumen. Treatment with $C$. borivilianum root extract has resulted in higher sperm count and epididymal sperm density which suggests that this herb protect the sperm against diabetes-induced damage. In

Table 6 Assessment of epididymal sperm density

\begin{tabular}{|c|c|c|c|c|c|}
\hline \multirow[t]{2}{*}{ Parameters } & \multirow[t]{2}{*}{ Normal } & \multirow[t]{2}{*}{ Diabetic } & \multicolumn{3}{|c|}{ Diabetic } \\
\hline & & & $250 \mathrm{mg} / \mathrm{kg}$ C. borivilianum & $500 \mathrm{mg} / \mathrm{kg}$ C. borivilianum & $600 \mu \mathrm{g} / \mathrm{kg}$ glibenclamide \\
\hline Epididymis sperm density & +++ & + & ++ & ++ & ++ \\
\hline
\end{tabular}

+++ Normal density, ++ moderately decreased density, + severely decreased. 

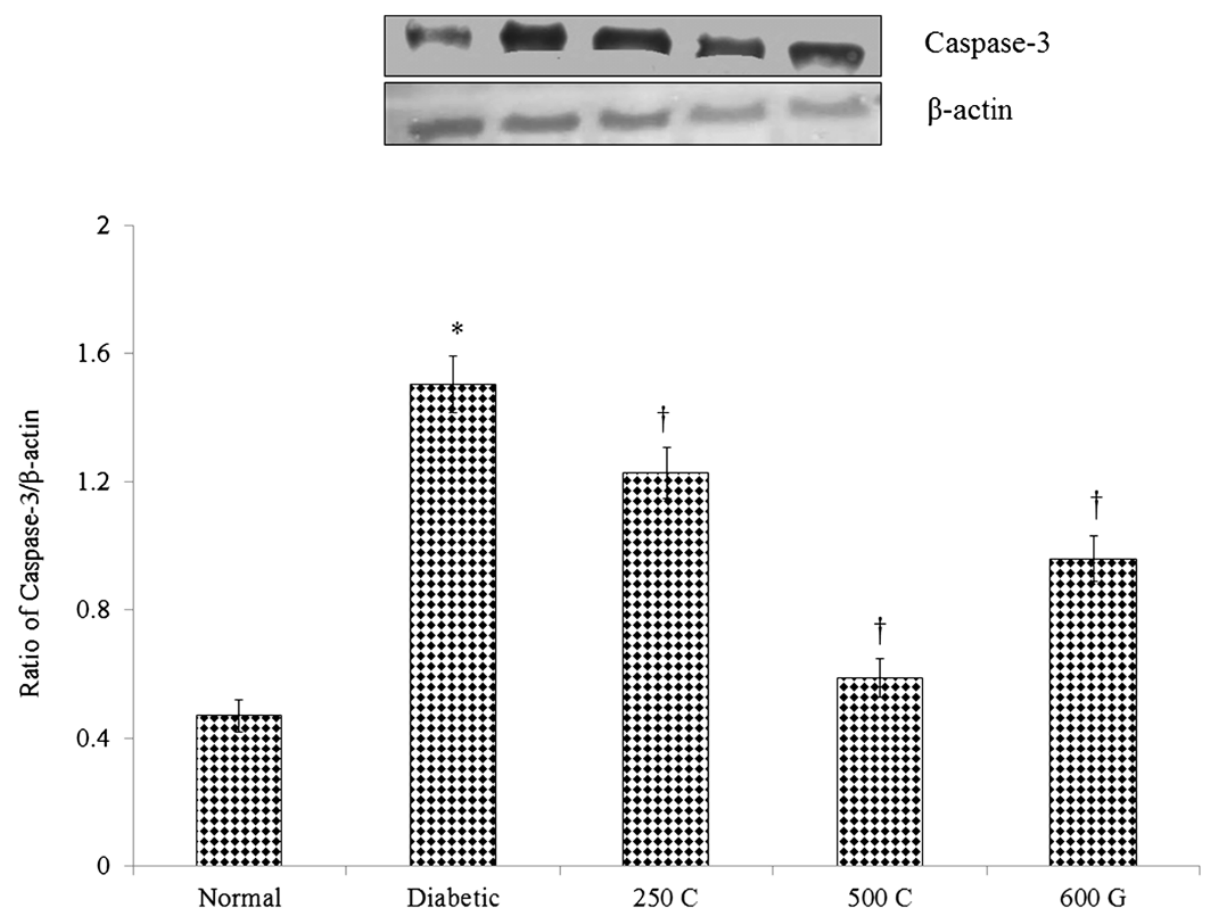

Figure 9 Expression of Caspase-3 protein in sperm. Administration of C. borivilianum root extract at 250 and $500 \mathrm{mg} / \mathrm{kg} / \mathrm{day}$ or glibenclamide to diabetic rats resulted in lower expression of caspase-3 protein as compared to non-treated diabetic rats. 250C: $250 \mathrm{mg} / \mathrm{kg} / \mathrm{day}$ C. borivilianum root extract; 500C: $500 \mathrm{mg} / \mathrm{kg} /$ day C. borivilianum root extract, $600 \mathrm{G}: 600 \mu \mathrm{g} / \mathrm{kg} /$ day glibenclamide. $\mathrm{n}=4$ bands per treatment group, ${ }^{*} \mathrm{p}<0.05$ as compared to normal, non-diabetic control rats, $+p<0.05$ as compared to non-treated diabetic rats. MW of caspase- 3 is $32 \mathrm{kDa}$ and $\beta$-actin is $43 \mathrm{kDa}$.

this study, lower percentage of forward moving sperm was also observed in diabetic rats as compared to normal, non-diabetic rats. Sperm with normal forward motility are capable of swimming through the female reproductive tract and ultimately fertilized the oocyte. This characteristic is largely acquired during sperm transit and storage in the epididymis [51]. Several factors including cAMP, intracellular $\mathrm{pH}$ and $\mathrm{Ca}^{2+}$ level could affect ability of the sperm to display these characteristics [52]. Further studies are required to investigate oxidative stress parameters in testis, epididymis and seminal fluid which would help to ascertain their contribution towards the increase in sperm oxidative stress which subsequently caused sperm damage.

The percentage of sperm viability was also reduced in diabetic rats consistent with reports in both rodents [51,53] and humans [54]. Kanter et al., [55] reported that in rats, diabetes could induce sperm apoptosis which resulted in reduced sperm viability. Similarly, higher caspase-3 expression was observed in this study which indicates increased sperm apoptosis in diabetes. 28-days treatment with $C$. borivilianum root extract to diabetic rats resulted in higher percentage of HOS tailcoiled sperm and lower percentage of abnormal sperm as well as sperm with various abnormal shapes. The reduced in percentage of HOS-tail coiled sperm which indicate inability of the sperm to display tail-coiled appearance upon placing into hypoosmotic solution [44] suggest reduced integrity of flagella membrane [56]. Besides membrane integrity assessment, HOS tail coiled test is also useful to evaluate sperm viability [57]. The reduced sperm viability which was parallel to the reduced appearance of HOS-tail coiled sperm has been reported in both diabetic rodents [19] and humans [5]. Our finding which indicates reduced expression of caspase- 3 in sperm of diabetic rats following $C$. borivilianum root extract treatment suggested that increased sperm viability was due to decreased in apoptosis. We speculated that the reduced appearance of HOS tail coiled sperm in diabetic rats could be due to increased in caspase-3, however this need further confirmation.

Diabetes induces oxidative-stress has been reported to cause peroxidation of sperm membrane lipid which might interfere with membrane fluidity and transport processes [58]. In view of this, appearance of various abnormal sperm shapes could be due to abnormal membrane or cellular and nuclear changes induced by diabetes [59]. More studies are needed to elucidate mechanisms underlying abnormal sperm appearances in diabetes. Treatment with $C$. borivilianum root extract prevents the increase in the amount of sperm lipid 
peroxidation as well as the levels of superoxide and nitric oxide free radical in sperm of diabetic rats. In both diabetic rats [19] and humans [60], lipid peroxidation was the major cause for sperm damage. Administration of C. borivilianum root extract to diabetic rats alleviates oxidative stress via several mechanisms which include reduced amount of free radicals such as superoxide and nitric oxide and preservation of total antioxidant capacity via maintaining near normal activity level of endogenous antioxidant enzymes. Additionally, a strong in-vitro free radical scavenging activity of the root extract further contribute towards the in-vivo free radical scavenging effects. The later effects may be attributed to higher amount of total phenolic content in the root extract as revealed by FTIR spectroscopic analysis. Meanwhile, ability of C. borivilianum root extract to lower FBG and $\mathrm{HbA1c}$ levels in diabetic rats could also help to reduce the risk of acquiring abnormal sperm morphology and characteristics and sperm oxidative stress [55,59]. Scarano et al. [61] reported that sperm counts in diabetic rats was diminished following short-term exposure to hyperglycemia, while Amaral et al. [62] reported that prolonged hyperglycemia in rats adversely affect sperm concentration and motility due to oxidative stress.

\section{Conclusion}

The root extract of $C$. borivilianum is potentially useful for male infertility treatment via overcoming impairment in sperm characteristics and via reducing percentage and appearance of abnormal sperm in diabetes. Additionally, the root extract also prevents elevation of sperm oxidative stress that might trigger apoptosis. Our findings therefore justify the claimed beneficial effects of C. borivilianum root extract on sperm in diabetes.

\section{Competing interests}

The authors declare that they have no competing interests.

\section{Authors' contributions}

NG, KEK and NS designed the study. NG and SSR collected test data and interpreted the results. NG, SM and NS drafted and approved the manuscript. All authors read and approved the final manuscript.

\section{Acknowledgement}

This study was funded by UMRG grant (UMRG - RP011-13HTM) University of Malaya, Kuala Lumpur, Malaysia.

\footnotetext{
Author details

${ }^{1}$ Department of Physiology, Faculty of Medicine, University of Malaya, 50603 Kuala Lumpur, Malaysia. ${ }^{2}$ Pharmacology Division, A.U. College of

Pharmaceutical Sciences, Andhra University, Visakhapatnam 530 003, Andhra Pradesh, India. ${ }^{3}$ Department of Zoology, Sri Venkateswara University, Tirupati 517502Andhra Pradesh, India. ${ }^{4}$ Department of Molecular Medicine, Faculty of Medicine, University of Malaya, Kuala Lumpur, Malaysia.
}

Received: 14 March 2014 Accepted: 23 July 2014

Published: 8 August 2014

\section{References}

1. Association AD: Diagnosis and classification of diabetes mellitus. Diabetes Care 2013, 36(Supplement 1):S67-S74.

2. Ryan JG, Gajraj J: Erectile dysfunction and its association with metabolic syndrome and endothelial function among patients with type 2 diabetes mellitus. J Diabetes Complicat 2012, 26(2):141-147.

3. Rama Raju GA, Jaya Prakash G, Murali Krishna K, Madan K, Siva Narayana T, Ravi Krishna $\mathrm{CH}$ : Noninsulin-dependent diabetes mellitus: effects on sperm morphological and functional characteristics, nuclear DNA integrity and outcome of assisted reproductive technique. Andrologia 2012, 44:490-498.

4. Thakur M, Thompson D, Connellan P, Deseo MA, Morris C, Dixit VK: Improvement of penile erection, sperm count and seminal fructose levels in vivo and nitric oxide release in vitro by ayurvedic herbs. Andrologia 2011, 43(4):273-277.

5. Bhattacharya SM, Ghosh M, Nandi N: Diabetes mellitus and abnormalities in semen analysis. J Obstet Gynaecol Res 2014, 40(1):167-171.

6. Lokhande $R$, Singare $P$, Andhale M: Study on mineral content of some Ayurvedic Indian medicinal plants by instrumental neutron activation analysis and AAS techniques. Health Sci J 2010, 4(3):157-168.

7. Khanam Z, Singh O, Singh R, Bhat IUH: Safed musli (Chlorophytum borivilianum): A review of its botany, ethnopharmacology and phytochemistry. J Ethnopharmacol 2013, 150(2):421-441.

8. Singh D, Pokhriyal B, Joshi YM, Kadam V: Phytopharmacological aspects of Chlorophytum borivilianum (safed musli): A review. Int J Res Pharm Chem 2012, 2:853-898.

9. Kenjale R, Shah R, Sathaye S: Effects of Chlorophytum borivilianum on sexual behaviour and sperm count in male rats. Phytother Res 2008, 22(6):796-801.

10. Thakur M, Bhargava S, Praznik W, Loeppert R, Dixit VK: Effect of Chlorophytum borivilianum Santapau and Fernandes on sexual dysfunction in hyperglycemic male rats. Chin J Integr Med 2009, 15(6):448-453.

11. Aitken RJST, Jobling MS, Baker MA, De luliis GN: Oxidative stress and male reproductive health. Asian J Androl 2014, 16(1):31-38.

12. Del Barco-Trillo J, Roldan ERS: Effects of metabolic rate and sperm competition on the fatty-acid composition of mammalian sperm. J Evol Biol 2014, 27(1):55-62.

13. Baumber J, Ball BA, Gravance CG, Medina V, Davies-Morel MCG: The effect of reactive oxygen species on equine sperm motility, viability, acrosomal integrity, mitochondrial membrane potential, and membrane lipid peroxidation. J Androl 2000, 21(6):895-902.

14. Tsunoda S, Kawano N, Miyado K, Kimura N, Fujii J: Impaired fertilizing ability of superoxide dismutase 1-deficient mouse sperm during in vitro fertilization. Biol Reprod 2012, 87(5):121. 121-126.

15. Attia YA, Kamel Kl: Semen quality, testosterone, seminal plasma biochemical and antioxidant profiles of rabbit bucks fed diets supplemented with different concentrations of soybean lecithin. Animal 2012, 6(Special Issue 05):824-833.

16. Mahfouz R, Sharma R, Sharma D, Sabanegh E, Agarwal A: Diagnostic value of the total antioxidant capacity (TAC) in human seminal plasma. Fertil Steril 2009, 91(3):805-811.

17. Harborne AJH, J. B: Phytochemical Methods: A Guide to Modern Techniques of Plant Analysis. 3rd edition. Springer; 1998.

18. OECD [Organisation for Economic Cooperation and Development]: Guidelines for Testing of Chemicals. Acute Oral Toxicity. No 401. Paris: OECD; 1981

19. Nelli GB, K AS, Kilari EK: Antidiabetic effect of a-mangostin and its protective role in sexual dysfunction of streptozotocin induced diabetic male rats. Syst Biol Reprod Med 2013, 59(6):319-328.

20. Mujeeb M, Khan SA, Ali M, Mall A, Ahmad A: Antidiabetic activity of the aqueous extract of Chlorophytum borivilianum L. in Streptozotocin induced- hyperglycemic rats-a preliminary study. J Pharm Res 2009, 2:5-53.

21. Belsey MA, Eliasson R, Gallegos AJ, Moghissi KS, Paulson CA, Prasad MRN World Health Organization: Laboratory Manual for the Examination of Human Semen and Semen-Cervical Mucus Interaction. Singapore: Press Concern; 1980.

22. Talbot $\mathrm{P}$, Chacon RS: A triple-stain technique for evaluating normal acrosome reactions of human sperm. J Exp Zoo 1981, 215(2):201-208.

23. Jeyendran RS, Van der Ven HH, Zaneveld L: The hypoosmotic swelling test: an update. Arch Androl 1992, 29(2):105-116. 
24. Bjorndahl L, Soderlund I, Johansson S, Mohammadieh M, Pourian MR, Kvist $\mathrm{U}$ : Why the WHO recommendations for eosin-nigrosin staining techniques for human sperm vitality assessment must change. J Androl 2004, 25(5):671-678.

25. Ohkawa $\mathrm{H}$, Ohishi N, Yagi K: Assay for lipid peroxidation in animal tissues by thiobarbituri acid reaction. Anal Biochem 1979, 95:351-358.

26. Pick E: Microassays for superoxide and hydrogen peroxide production and nitroblue tetrazolium reduction using an enzyme immunoassay microplate reader. Methods Enzymol 1986, 132:407-421.

27. Miranda KM, Espey MG, Wink DA: A rapid, simple spectrophotometric method for simultaneous detection of nitrate and nitrite. Nitric Oxide 2001, 5(1):62-71.

28. Erel O: Novel automated method to measure total antioxidant response against potent free radical reactions. Clin Biochem 2004, 37:112-119.

29. Misra HPFI: The role of superoxide anion in the autoxidation of epinephrine and a simple assay for superoxide dismutase. J Biol Chem 1972, 247(10):3170-3175

30. Maehly A, Chance B: Catalases and peroxidases. Methods Biochem Anal 1954, 1:357-424

31. Rotruck JTPA, Ganther HE, Swanson AB, Hafeman DG, Hoekstra WG: Selenium: biochemical role as a component of glutathione peroxidase. Science 1973, 179(4073):588-590.

32. Katalinic V, Milos M, Kulisic T, Jukic M: Screening of 70 medicinal plant extracts for antioxidant capacity and total phenols. Food Chem 2006, 94:550-557.

33. Xiang Z, Ning Z: Scavenging and antioxidant properties of compound derived from chlorogenic acid in South-China honeysuckle. LWT- Food Sci Technol 2008, 41(7):1189-1203.

34. Halliwell B, Gutteridge J, Aruoma O: The deoxyribose method: a simple "test-tube" assay for determination of rate constants for reactions of hydroxyl radicals. Anal Biochem 1987, 165:215-219.

35. Ruch RJ, Cheng S-j, Klaunig JE: Prevention of cytotoxicity and inhibition of intercellular communication by antioxidant catechins isolated from Chinese green tea. Carcinogenesis 1989, 10(6):1003-1008.

36. Dastmalchi K, Damien Dorman HJ, Oinonen PP, Darwis Y, Laakso I, Hiltunen $\mathrm{R}$ : Chemical composition and in vitro antioxidative activity of a lemon balm (Melissa officinalis L.) extract. LWT- Food Sci Technol 2008, 41:391-400.

37. Suseela VGV, Varghese S: In vitro antioxidant studies of fruits of artemisia nilagirica (Clarke) pamp. Indian J Pharm Sci 2010, 72(5):644-649.

38. Narayana K, Prashanthi N, Nayanatara A, Kumar SG, Kumar HHC, Bairy KL, D'Souza UJA: A broad-spectrum organophosphate pesticide O, O-dimethyl O-4-nitrophenyl phosphorothioate (methyl parathion) adversely affects the structure and function of male accessory reproductive organs in the rat. Environ Toxicol Pharmacol 2006, 22(3):315-324

39. Lobo V, Patil A, Phatak A, Chandra N: Free radicals, antioxidants and functional foods: Impact on human health. Pharmacogn Rev 2010, 4(8):118.

40. Devi PS, Kumar MS, Das SM: DNA damage protecting activity and free radical scavenging activity of anthocyanins from red Sorghum (Sorghum bicolor) Bran. Biotechnol Res Int 2012, 2012.

41. Sahoo S, Ghosh G, Das D, Nayak S: Phytochemical investigation and In vitro antioxidant activity of an indigenous medicinal plant Alpinia nigra B.L. Burtt. Asian Pac J Trop Biomed 2013, 3(11):871-876.

42. Pacher $P$, Beckman JS, Liaudet L: Nitric oxide and peroxynitrite in health and disease. Physiol Rev 2007, 87(1):315-424

43. Adedapo A, Ofuegbe SO: The evaluation of the hypoglycemic effect of soft drink leaf extract of Phyllanthus amarus (Euphorbiaceae) in rats. J Basic Clin Physiol Pharmacol 2014, 25(1):47-57.

44. World Health Organization, Department of Reproductive Health and Research: WHO Laboratory Manual for the Examination and Processing of Human Semen. 5th edition. Geneva: WHO Press; World Health Organization; 2010.

45. Altay B, Cetinkalp S, Doganavsargil B, Hekimgil M, Semerci B: Streptozotocin-induced diabetic effects on spermatogenesis with proliferative cell nuclear antigen immunostaining of adult rat testis. Fertil Steril 2003, 80(Suppl 2):828-831.

46. Rabbani SI, Devi K, Khanam S: Pioglitazone, a PPAR-gamma ligand inhibited the nicotinamide-streptozotocin induced sperm abnormalities in type-2 diabetic Wistar rats. Pak J Pharm Sci 2010, 23(3):326-331.

47. Bal R, Turk G, Tuzcu M, Yilmaz O, Ozercan I, Kuloglu T, Gur S, Nedzvetsky VS, Tykhomyrov AA, Andrievsky GV, Baydas G, Naziroglu M: Protective effects of nanostructures of hydrated $\mathrm{C}(60)$ fullerene on reproductive function in streptozotocin-diabetic male rats. Toxicology 2011, 282(3):69-81.

48. Oyeyipo IPRY, Emikpe BO, Bolarinwa AF: Effects of nicotine on sperm characteristics and fertility profile in adult male rats: a possible role of cessation. J Reprod Infertil 2011, 12(3):201-207.

49. Heidari-Vala HEHR, Sadeghi MR, Akhondi MM, Ghaffari Novin M, Heidari M: Evaluation of an aqueous-ethanolic extract from Rosmarinus officinalis (Rosemary) for its activity on the hormonal and cellular function of testes in adult male rat. Iran J Pharm Res 2013, 12(2):445-451.

50. Noguchi S, Ohba Y, Oka T: Involvement of epidermal growth factor deficiency in pathogenesis of oligozoospermia in streptozotocin-induced diabetic mice. Endocrinology 1990, 127(5):2136-2140.

51. Abbasi Z, Tabatabaei SRF, Mazaheri Y, Barati F, Morovvati H: Effects of sesame Oil on the reproductive parameters of diabetes mellitus-induced male rats. World J Mens Health 2013, 31(2):141-149.

52. Han YHC, Feng HL: Role(s) of the serine/threonine protein phosphatase 1 on mammalian sperm motility. Arch Androl 2007, 53(4):169-177.

53. Khaki A, Fathiazad F, Nouri M, Khaki A, Maleki NA, Khamnei HJ, Ahmadi P: Beneficial effects of quercetin on sperm parameters in streptozotocininduced diabetic male rats. Phytother Res 2010, 24(9):1285-1291.

54. La Vignera S, Condorelli R, Vicari E, D'Agata R, Calogero AE: Diabetes mellitus and sperm parameters. J Androl 2012, 33(2):145-153.

55. Kanter M, Aktas C, Erboga M: Protective effects of quercetin against apoptosis and oxidative stress in streptozotocin-induced diabetic rat testis. Food Chem Toxicol 2012, 50(3-4):719-725.

56. Matson P, Kappelle W, Malecki I: The use of a hypo-osmotic swelling (HOS) test on sperm of the pig (Sus scrofa domesticus), emu (Dromaius novaehollandiae), Asian elephant (Elephas maximus), hamadryas baboon (Papio hamadryas hamadryas), and central rock rat (Zyzomys pedunculatus). Reprod Biol 2009, 9(2):181-187.

57. Munuce MJCA, Berta CL, Perfumo P, Morisoli L: Does the hypoosmotic swelling test predict human sperm viability? Arch Androl 2000, 44(3):207-212.

58. Sanocka D, Kurpisz M: Reactive oxygen species and sperm cells. Reprod Biol Endocrinol 2004, 2(1):12.

59. Suresh S, Prithiviraj E, Venkata Lakshmi N, Karthik Ganesh M, Ganesh L, Prakash S: Effect of Mucuna pruriens (Linn.) on mitochondrial dysfunction and DNA damage in epididymal sperm of streptozotocin induced diabetic rat. J Ethnopharmacol 2013, 145(1):32-41.

60. Karimi J, Goodarzi MT, Tavilani H, Khodadadi I, Amiri I: Relationship between advanced glycation end products and increased lipid peroxidation in semen of diabetic men. Diabetes Res Clin Pract 2011, 91(1):61-66

61. Scarano WR, Messias AG, Oliva SU, Klinefelter GR, Kempinas WG: Sexual behaviour, sperm quantity and quality after short-term streptozotocininduced hyperglycaemia in rats. Int J Androl 2006, 29(4):482-488.

62. Amaral S, Moreno AJ, Santos MS, Seiça R, Ramalho-Santos J: Effects of hyperglycemia on sperm and testicular cells of Goto-Kakizaki and streptozotocin-treated rat models for diabetes. Theriogenology 2006, 66(9):2056-2067.

\section{doi:10.1186/1472-6882-14-291}

Cite this article as: Giribabu et al:: Chlorophytum borivilianum (Safed

Musli) root extract prevents impairment in characteristics and elevation of oxidative stress in sperm of streptozotocin-induced adult male diabetic Wistar rats. BMC Complementary and Alternative Medicine 2014 14:291. 